\title{
Residual nitrogen fertilization effect of common bean production on succeeding corn intercropped with Congo grass ${ }^{1}$
}

\author{
Antonio Carlos de Almeida Carmeis Filho ${ }^{2 *}$, Tatiana Pagan Loeiro da Cunha ${ }^{3}$, Fábio Luiz Checchio Mingotte ${ }^{3}$, \\ Isaac Silva Martins ${ }^{3}$, Leandro Borges Lemos ${ }^{3}$, Domingos Fornasieri Filho ${ }^{3}$
}

$10.1590 / 0034-737 X 201663040019$

\begin{abstract}
Crop production in conservation systems involving intercropped cultivations mainly with corn have been proposed as a technology to promote sustainability in the Brazilian Cerrado areas. The objective of this work was to evaluate the influence of residual nitrogen fertilization applied in common bean on subsequent corn sole or intercropped with Congo grass (Urochloa ruziziensis) in no-tillage system. The experiment was carried out in randomized blocks with three replicates in a split-plot design. The treatments were composed by two cropping systems (sole and intercropped with Congo grass), and the sub-plots were five doses of nitrogen $\left(0 ; 40 ; 80 ; 120\right.$ and $\left.160 \mathrm{~kg}_{\text {of N ha }}{ }^{-1}\right)$, applied in topdressing on common-bean (previous crop). There was no effect of cropping systems and residual amount of nitrogen application in the vegetative and reproductive development of corn. Corn intercropped with Congo grass leaded an adequate formation of crop residue and total land covering target at sustainability of no-tillage system.
\end{abstract}

Key-words: Zea mays; Urochloa ruziziensis; crop system; straw.

\section{RESUMO}

\section{Efeito residual da adubação nitrogenada no feijoeiro comum sobre o milho subsequente consorciado com braquiária}

Sistemas conservacionistas de produção envolvendo cultivos consorciados, principalmente com milho, têm sido propostos como tecnologia para promover a sustentabilidade em áreas do Cerrado brasileiro. Diante desses aspectos, o objetivo do trabalho foi avaliar a influência da adubação nitrogenada residual aplicada no feijoeiro comum em subsequente cultivo de milho exclusivo e consorciado com braquiária (Urochloa ruziziensis), no sistema plantio direto. O delineamento experimental utilizado foi o de blocos casualizados, em esquema de parcelas subdivididas, com três repetições. As parcelas foram representadas por dois sistemas de cultivo contendo milho exclusivo e consorciado com braquiária e as subparcelas foram constituídas por cinco doses de nitrogênio $\left(0,40,80,120\right.$ e $\left.160 \mathrm{~kg} \mathrm{ha}^{-1} \mathrm{de} \mathrm{N}\right)$, aplicadas em cobertura no feijoeiro (cultura antecessora). Destaca-se que não houve efeito dos sistemas de cultivo e das doses residuais de aplicação de $\mathrm{N}$ sobre o desenvolvimento vegetativo e reprodutivo do milho. O consórcio de braquiária e milho permitiu adequada formação de palhada e total recobrimento da superfície do solo objetivando a qualidade e sustentabilidade do sistema plantio direto.

Palavras-chave: Zea mays; Urochloa ruziziensis; sistema de cultivo; palhada.

Submitted on August $5^{\text {th }}, 2014$ and accepted on May $4^{\text {th }}, 2016$

'This paper is part of Master's dissertation of the first author, presented to the Departamento de Produção Vegetal of Universidade Estadual Paulista "Júlio de Mesquita Filho", Jaboticabal, São Paulo, Brazil.

${ }^{2}$ Universidade Estadual Paulista “Júlio de Mesquita Filho”, Faculdade de Ciências Agronômicas, Botucatu, São Paulo, Brazil. tonycarmeis@hotmail.com

${ }^{3}$ Universidade Estadual Paulista “Júlio de Mesquita Filho”, Faculdade de Ciências Agrárias e Veterinárias, Campus de Jaboticabal, Jaboticabal, São Paulo, Brazil. tatiana.pagan @ hotmail.com; flcmingotte@gmail.com; isaac_agro@hotmail.com; leandrobl@fcav.unesp.br; fornasieri@fcav.unesp.br

*Corresponding author: tonycarmeis@ @otmail.com

Rev. Ceres, Viçosa, v. 63, n.4, p. 576-583, jul/ago, 2016 


\section{INTRODUCTION}

Although grown in a season with climate unfavorable for maximum agronomic performance, the off-season corn has accounted for approximately $65 \%$ of total Brazilian production (CONAB, 2016). Among the main aspects related with viability and expansion of the crop in the offseason is the evolution of conservationist production systems, such as no-tillage and cultivation strategies with perennial forages, especially Urochloa species (Pariz et al., 2009; Chioderoli et al., 2012). Among the forages intercropped with corn, Congo grass (Urochloa ruziziensis) distinguish due to rapid establishment and excellent formation of straw, considering that the forage produces large amount of dry matter until sowing of the next crop, giving full protection to the soil surface (Souza et al., 2011; Freitas et al., 2013; Cunha et al., 2015). Furthermore, Urochloa species are considered great restorer of soil organic matter, in addition to promoting higher nutrient cycling in agricultural production systems (Batista et al., 2011).

Nitrogen $(\mathrm{N})$ is characterized as the main nutrient for corn grain yield, and exerts great effect on the costs of this cereal production. In order to improve environmental sustainability, nutrient management strategies are needed to optimize the use of chemical fertilizers. Optimizing nitrogen fertilizer application to agriculture cropping systems leads to reduce economic and environmental issues, in addition, it is important to prevent nutrient deficiencies that limit the productive potential of the crop (Amado et al., 2002; Kappes et al., 2009). Considering these aspects, it is a constant challenge to establish the prescription of appropriate rates, both for the nutritional and the economic aspects. It should be highlighted that the demand for $\mathrm{N}$ may be even greater than the recommended (Batista et al., 2011), so it is extremely important to carry out further studies in this area.

In conservation systems, the preceding crop is seen as one of the main criteria for the recommendation of nitrogen fertilization for growing corn under no-tillage system. The use of Fabaceae species and high amounts of fertilizer used in the agricultural production system may provide residual effect on subsequent crops, reducing the demand for application of nitrogen mineral fertilizers in the following crop (Fernandes et al., 2008).

Scientific results show that stabilization of the notillage system provides increase in total soil nitrogen stocks, which is detected by the reflection in the reduction of losses, especially in erosion, leaching and denitrification processes, and with the increase in additions by means of symbiotic process of atmospheric $\mathrm{N}$ fixation and the inclusion of organic residue (D'Andréa et al., 2004; Sou- za et al., 2009). Lovato et al. (2004) evidenced that the practice of grass rotation with Fabaceae family and nitrogen fertilization are the preponderant factors for the largest annual addition of $\mathrm{N}$ to the soil, a fact directly related to the productivity of corn grain. Therefore, the study of the management of nitrogen fertilization in different cropping systems is of fundamental importance because it is one of the ways to achieve the reduction of costs in cereal production.

Therefore, the objective of this study was to evaluate the influence of residual nitrogen fertilizer applied in the previous common bean in corn intercropped or not with $U$. ruziziensis in no-tillage system.

\section{MATERIAL AND METHODS}

The experiment was carried out in Jaboticabal, state of São Paulo, located at latitude $21^{\circ} 14^{\prime} 33^{\prime \prime}$ S and longitude $48^{\circ} 17^{\prime} 10^{\prime \prime} \mathrm{W}$, at 565 meters above sea level. According to the classification proposed by Köeppen, the climate in the region is Aw, characterized as humid tropical, with the rainy season in summer and dry season in winter. The soil is classified as clayey Oxisol, with $533 \mathrm{~g} \mathrm{~kg}^{-1}$ clay, $193 \mathrm{~g} \mathrm{~kg}$ ${ }^{-1}$ silt and $274 \mathrm{~g} \mathrm{~kg}^{-1}$ of sand, mild rolling relief, being grown in the crop years of 2008/09, 2009/10 and 2010/11 with corn and Brachiaria ruziziensis in summer following spring common bean.

Chemical analysis of soil fertility in the 0-20 cm layer, according to the methodology described by Raij et al. (2001), allowed to observe the following values: $\mathrm{pH}\left(\mathrm{CaCl}_{2}\right)$ : 5.4; O.M. $\left(\mathrm{g} \mathrm{dm}^{-3}\right): 22$; Presin $\left(\mathrm{mg} \mathrm{dm}^{-3}\right): 82 ; \mathrm{H}+\mathrm{Al} ; \mathrm{K}$; Ca; $\mathrm{Mg} ; \mathrm{SB} ; \mathrm{CEC}\left(\mathrm{mmol}_{\mathrm{c}} \mathrm{dm}^{-3}\right): 25 ; 5.7 ; 28 ; 13 ; 46 ; 71$; and V: $65 \%$, respectively.

The experimental design was randomized block in a split-plot design with three replications. The plots were represented by two cropping systems (sole and intercropped-cropped with Urochloa ruziziensis), following irrigated common bean crop (grown in the winter-spring period). The subplots were composed of five rates of nitrogen applied in topdressing in common bean crop $\left(0,40,80,120\right.$ and $\left.160 \mathrm{~kg} \mathrm{~N} \mathrm{ha}^{-1}\right)$ at the phenological stage $\mathrm{V}_{4-4}$ (50\% of plants with four fully expanded trifoliate leaves) using urea as a source, which were placed at $10 \mathrm{~cm}$ from the growing row in continuous fillet.

Common bean cultivar IAC Formoso was sown on August 19, 2011, where 12 viable seeds were mechanically distributed per meter, at spacing of $0.45 \mathrm{~m}$ between rows, equivalent to 266,000 plants $\mathrm{ha}^{-1}$. Harvest was performed manually on November, 18, 2011. Corn sowing was carried out on January, 21, 2012, a period considered as second crop (off-season). In both crop systems, the simple hybrid DKB 390 PRO2 was used in the population density of 
60,000 plants $^{-1} \mathrm{a}^{-1}$, with rows spaced at $0.80 \mathrm{~m}$. Sowing fertilization consisted of $330 \mathrm{~kg} \mathrm{ha}^{-1}$ of the commercial formula 04-14-08. In topdressing, $80 \mathrm{~kg} \mathrm{~N} \mathrm{ha}^{-1}$ and $80 \mathrm{~kg}$ $\mathrm{ha}^{-1} \mathrm{~K}_{2} \mathrm{O}$ was used by employing the commercial formula 20-00-20 at $\mathrm{V}_{4}$ leaf stage (four fully expanded leaves) and $100 \mathrm{~kg} \mathrm{~N}^{-1} \mathrm{a}^{-1}$ via urea in $\mathrm{V}_{6}(50 \%$ of the plants with six fully expanded leaves), followed by the application of a water depth of $15 \mathrm{~mm}$ by conventional spraying. Each subplot was composed of six corn rows spaced at $0.80 \mathrm{~m}$ and $5 \mathrm{~m}$ in length. The two central rows of each subplot were considered as the useful area, disregarding $0.5 \mathrm{~m}$ at each end.

When intercropped with Congo grass, forage sowing was carried out at the density of 400 points of cultural value $\mathrm{ha}^{-1}\left(7.5 \mathrm{~kg}\right.$ of seeds ha- $\left.{ }^{-1}\right)$ at the time of corn sowing at the proportion of two rows between the rows of corn. The intercropped corn was conducted under the same procedures as the sole crop. Corn harvest, single and intercropped, was carried out June 4th, 2012. The weather data recorded during corn and Congo grass growth are in Figure 1.

During the experimental period, the following characters were evaluated: a) plant height and first spike insertion height at the end of the cycle of ten corn plants, from ground level to the flag leaf and from ground level to the first spike insertion of the plant, respectively; b) the diameter of rachis, measuring the central third of ten ears; c) the length of the cob, calculated using the average of ten ears; d) the number of rows per ear and of kernels per row, determinated by counting the number of grains in a row and the number of rows in each spike; e) the mass of grains per spike, measured by the mean of the mass of grain of ten ears (moisture content adjusted to 13\%); f) 1000-grain weight, determined by counting and weighing eight samples obtained from each subplot; g) mass and diameter of the cob; $\mathrm{h}$ ) grain yield ( $\mathrm{kg} \mathrm{ha}^{-1}$ to $13 \%$ moisture) obtained after harvesting the two central rows of each subplot; i) crude protein content in grains, determined by multiplying the total $\mathrm{N}$ in the grains $\mathrm{x} 6.25$, expressed in $\mathrm{g}$ $\mathrm{kg}^{-1}$ (Malavolta et al, 1997); j) the grain size distribution was performed by passing the grains through a set of sieves; elongated sieve no. 18 (18/64" pol) and round holes, number 18 (18/64" pol), 20 (20/64"pol) 22 (22/64"pol) and 24 (24/64"pol) (Andrade et al., 2001). After a minute of mechanical stirring, the fraction retained on each sieve was weighed and the data transformed into percentage of grains retained on each sieve.

After the corn harvest, in both crop systems, covering and amount of straw on the soil were determined. For this, two samples per plot were collected with the aid of a wooden frame with inner dimensions of $0.5 \times 0.5 \mathrm{~m}$, and the samples were washed and dried in a forced air ventilation oven at $65^{\circ} \mathrm{C}$ until constant mass. In addition, $\mathrm{N}$ accumulated content was determined in the straw according to the methodology of Malavolta et al. (1997).

Data were submitted to analysis of variance by $F$ test and means were compared by the method of Tuckey at $5 \%$. Significant effects for residual effect of $\mathrm{N}$ and the interaction of cropping systems $\times$ residual effect of $\mathrm{N}$ were evaluated by polynomial regression analysis.

\section{RESULTS AND DISCUSSION}

From the obtained estimates, the morphological parameters and the yield components of the corn were not affected by the presence of forage specie $(p<0.05)$

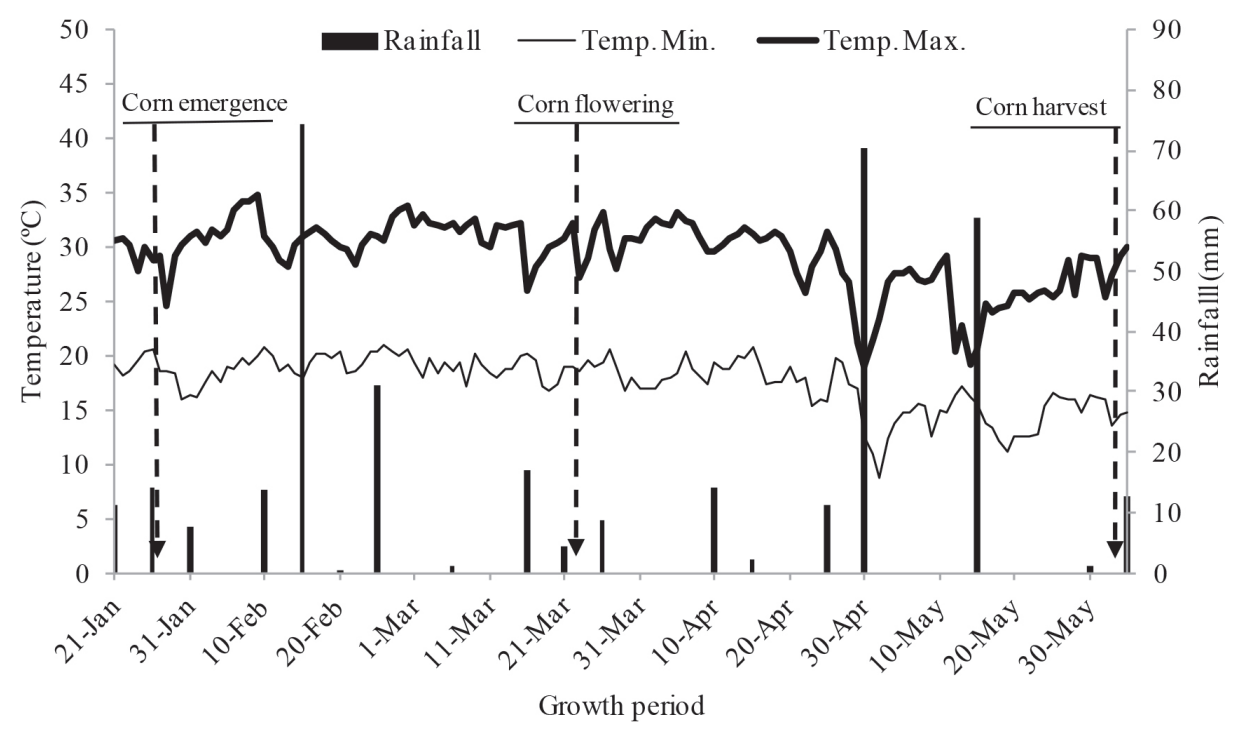

Figure 1: Rainfall (mm), maximum and minimum temperature $\left({ }^{\circ} \mathrm{C}\right)$, every ten days from January to June in 2012, on corn intercropped or not with U. ruziziensis. Source: Estação Agroclimatológica do Campus da FCAV/UNESP - Jaboticabal, SP. 2012. 
(Table 1), confirming the viability of this practice. Similar results were also obtained by Chioderoli et al. (2012) and Freitas et al. (2013). The researchers found that the intercropping with Congo grass, sown simultaneously with corn, did not affect corn grain yield, in addition, it increased organic residues input in the no-till crop production system. On the other hand, the results may be variable according intercropping modalities. Results obtained by Richart et al. (2010) demonstrated that the presence of the forage, since the beginning of the crop development, may impair the grain yield up to $16 \%$ compared to the sole crop.

It is noteworthy that in both crop systems (sole and intercropped), corn obtained grain yield higher than 6,800 $\mathrm{kg} \mathrm{ha}^{-1}$ (Table 2), while the average yield recorded for the State of São Paulo, in the same period, was $4,490 \mathrm{~kg} \mathrm{ha}^{-1}$ (CONAB, 2013). It is important emphasize that irregular distribution of rainfall occurred during the crop cycle, with water deficit in the critical period of plant development (Figure 1), that is, between the tassel initiation (Vt) and the beginning of silking $\left(\mathrm{R}_{1}\right)$ (Fornasieri Filho, 2007). Even under stress condition, the no-tillage system promotes greater water storage in the soil, which changes the soilwater relationship, and favors the development of grain (Stone et al., 2006). In addition, adequate water supply during the dough stage $\left(\mathrm{R}_{4}\right)$, phase when assimilates were translocated to grains (Fornasieri Filho, 2007), favoring their formation. Given these factors, the grain yield obtained exceeds the national average in approximately $2,300 \mathrm{~kg} \mathrm{ha}^{-1}$.

Regarding the use of residual $\mathrm{N}$ applied to common bean plants grown previously, no effect was observed on the subsequent cultivation for any of phytotechnical and reproductive parameters evaluated (Table 1). The high rate of nitrogen fertilizer (193 $\mathrm{kg} \mathrm{N} \mathrm{ha}^{-1}$ ) applied during the corn cycle and the reduction of inorganic $\mathrm{N}$ losses by natural processes, resulting from conservationist conditions of the no-tillage system, may have hidden these results. Furthermore, the inclusion of Fabaceae in rotation/ succession rotation crop systems may contribute significantly to the $\mathrm{N}$ intake in the soil via the symbiotic process with Rhizobium bacterias (Lovato et al., 2004; Souza et al, 2011.). According to results observed by Fernandes et al. (2008), the absence of residual effect is explained by the fact that the remaining inorganic $\mathrm{N}$ fertilizer occur predominantly in the form of organic compounds. Given this aspect, the use by subsequent crops remains generally very low.

Regarding the 1,000-grain weight (Table 2) and the grain size distribution (Table 3 and Figure 2), it can be stated that the development of Congo grass concurrently with corn did not affect the formation and size of reproductive structures. With respect to grain form, approximately $80 \%$ of the grains were classified as flat, regardless of the crop system. Due to the wide variation in the size, shape and quality of grain in the ear, grain

Table 1: F-values calculated by analysis of variance for corn parameters under influence of residual nitrogen fertilization of common bean on subsequent corn sole or intercropped with Congo grass (Urochloa ruziziensis) in no-tillage system ${ }^{1}$. Jaboticabal, SP. 2012

\begin{tabular}{|c|c|c|c|c|}
\hline & $\begin{array}{l}\text { Plant } \\
\text { height }\end{array}$ & $\begin{array}{c}\text { First spike } \\
\text { insertion height }\end{array}$ & $\begin{array}{l}\text { Rachis } \\
\text { diameter }\end{array}$ & $\begin{array}{l}\text { Spike } \\
\text { length }\end{array}$ \\
\hline Crop system (S) & $4.00^{\mathrm{ns}}$ & $3.53^{\mathrm{ns}}$ & $2.18^{\mathrm{ns}}$ & $0.05^{\text {ns }}$ \\
\hline $\mathrm{CV}(\%)$ & 2.96 & 2.80 & 1.24 & 5.16 \\
\hline $\mathrm{N}$ amount (D) & $0.60^{\mathrm{ns}}$ & $2.49^{\mathrm{ns}}$ & $0.40^{\mathrm{ns}}$ & $0.50^{\mathrm{ns}}$ \\
\hline CV $(\%)$ & 3.26 & 2.21 & 2.55 & 5.11 \\
\hline \multirow[t]{2}{*}{$\mathrm{S} \times \mathrm{D}$} & $0.33^{\text {ns }}$ & $0.65^{\mathrm{ns}}$ & $0.13^{\mathrm{ns}}$ & $0.78^{\mathrm{ns}}$ \\
\hline & $\begin{array}{c}\text { Number of } \\
\text { grains per row }^{-1}\end{array}$ & $\begin{array}{c}\text { Number of } \\
\text { grains per spike }^{-1}\end{array}$ & $\begin{array}{l}\text { Grain mass } \\
\text { per spike }^{-1}\end{array}$ & $\begin{array}{l}\text { 1,000-grain } \\
\text { weight }\end{array}$ \\
\hline Crop system (S) & $0.12^{\mathrm{ns}}$ & $0.64^{\mathrm{ns}}$ & $4.08^{\mathrm{ns}}$ & $1.10^{\mathrm{ns}}$ \\
\hline $\mathrm{CV}(\%)$ & 2.43 & 7.52 & 4.37 & 5.68 \\
\hline $\mathrm{N}$ amount (D) & $0.11^{\mathrm{ns}}$ & $0.26^{\mathrm{ns}}$ & $0.52^{\mathrm{ns}}$ & $0.19^{\mathrm{ns}}$ \\
\hline CV (\%) & 5.73 & 4.09 & 9.17 & 7.90 \\
\hline \multirow[t]{2}{*}{$\mathrm{S} \times \mathrm{D}$} & $1.46^{\mathrm{ns}}$ & $0.89^{\mathrm{ns}}$ & $0.22^{\mathrm{ns}}$ & $0.82^{\mathrm{ns}}$ \\
\hline & Cob mass & Cob diameter & Grain yield & Protein content \\
\hline Crop system (S) & $0.76^{\mathrm{ns}}$ & $0.87^{\mathrm{ns}}$ & $0.01^{\mathrm{ns}}$ & $0.04^{\mathrm{ns}}$ \\
\hline $\mathrm{CV}(\%)$ & 13.04 & 1.77 & 11.40 & 9.72 \\
\hline $\mathrm{N}$ amount (D) & $0.12^{\mathrm{ns}}$ & $0.27^{\mathrm{ns}}$ & $0.86^{\mathrm{ns}}$ & $0.80^{\mathrm{ns}}$ \\
\hline $\mathrm{CV}(\%)$ & 13.20 & 3.83 & 9.01 & 12.95 \\
\hline$S \times D$ & $0.21^{\mathrm{ns}}$ & $0.37^{\mathrm{ns}}$ & $1.66^{\mathrm{ns}}$ & $0.52^{\mathrm{ns}}$ \\
\hline
\end{tabular}

1 ns not significant by the $\mathrm{F}$ test at $5 \%$ of error probability. 
classification is seen as one of the main quality factors, for many researchers attribute this to the high correlation with the weight and grain volume (Baudet \& Misra, 1991; Ferreira et al., 2001).

For the production of straw, soil cover and $\mathrm{N}$ accumulation in the straw, some advantages of the intercropping with Congo grass were found (Tables 4 and 5). By comparing the two cropping systems, more promising results were found with the establishment of the intercropping. In this crop system, the amount of straw on the soil surface increased significantly (totaling 8.6 ton $\left.\mathrm{ha}^{-1}\right)$, favoring the soil cover $(100 \%)$ for subsequent crop sowing. Similar results were verified by Cunha et al. (2015), in addition the authors emphasized that the corn and Congo grass modality is an excellent option for increase the deposition and straw persistence in the soil,

Table 2: Corn parameters as affected by different crop systems. Jaboticabal, SP. 2012

\begin{tabular}{|c|c|c|c|c|}
\hline & $\begin{array}{c}\text { Plant } \\
\text { height }(\mathrm{m})\end{array}$ & $\begin{array}{c}\text { First spike } \\
\text { insertion height }(\mathrm{m})\end{array}$ & $\begin{array}{c}\text { Rachis } \\
\text { diameter }(\mathrm{mm})\end{array}$ & $\begin{array}{c}\text { Spike } \\
\text { length }(\mathrm{cm})\end{array}$ \\
\hline Corn & $2.36 \mathrm{a}^{1}$ & $1.31 \mathrm{a}$ & $52.0 \mathrm{a}$ & $15.9 \mathrm{a}$ \\
\hline \multirow[t]{2}{*}{ Corn $+U$. ruziziensis } & $2.31 \mathrm{a}$ & $1.33 \mathrm{a}$ & $51.6 \mathrm{a}$ & $16.0 \mathrm{a}$ \\
\hline & $\begin{array}{c}\text { Number of } \\
\text { grains per row }^{-1}\end{array}$ & $\begin{array}{l}\text { Number of } \\
\text { rows spike }^{-1}\end{array}$ & 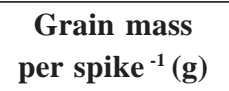 & $\begin{array}{l}\text { 1,000-grain } \\
\text { weight }(g)\end{array}$ \\
\hline Corn & $27.4 \mathrm{a}$ & $18.0 \mathrm{a}$ & $184.9 \mathrm{a}$ & $322.2 \mathrm{a}$ \\
\hline \multirow[t]{2}{*}{ Corn $+U$. ruziziensis } & $27.4 \mathrm{a}$ & $18.4 \mathrm{a}$ & $179.0 \mathrm{a}$ & $315.2 \mathrm{a}$ \\
\hline & $\begin{array}{c}\text { Cob } \\
\text { mass (g) }\end{array}$ & $\begin{array}{c}\text { Cob } \\
\text { diameter }(\mathrm{mm})\end{array}$ & $\begin{array}{c}\text { Grain } \\
\text { yield }\left(\mathrm{kg} \mathrm{ha}^{-1}\right)\end{array}$ & $\begin{array}{c}\text { Protein } \\
\text { content }\left(\mathrm{g} \mathrm{kg}^{-1}\right)\end{array}$ \\
\hline Corn & $40.0 \mathrm{a}$ & $29.6 \mathrm{a}$ & $6,879 \mathrm{a}$ & $83.1 \mathrm{a}$ \\
\hline Corn $+U$. ruziziensis & $41.7 \mathrm{a}$ & $29.7 \mathrm{a}$ & 6,865 a & $83.7 \mathrm{a}$ \\
\hline
\end{tabular}

${ }^{1}$ Means followed by the same letter do not differ significantly by the test of Tuckey at $5 \%$ of significance.

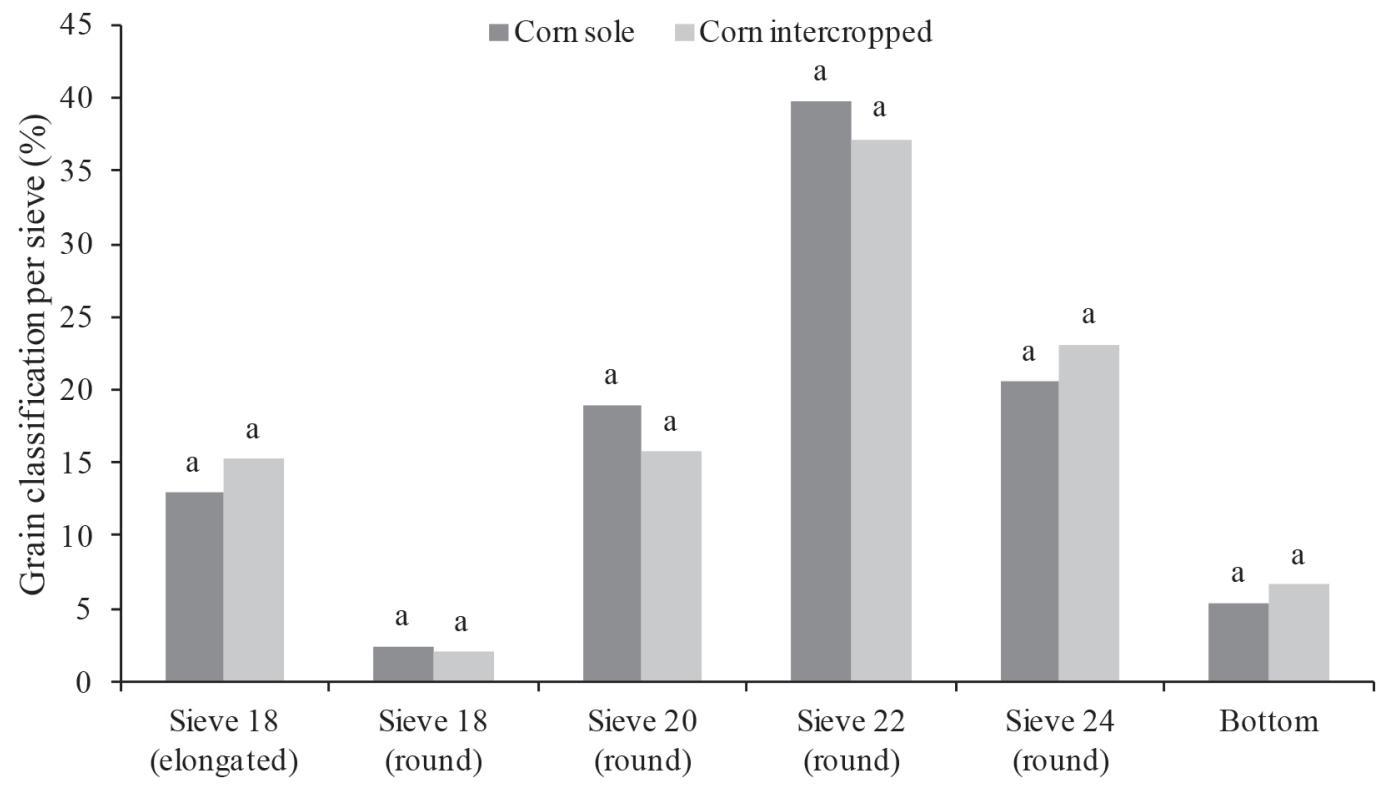

Figure 2: Grain size distribution of corn as affected by different crop system. Means followed by the same letter in each sieve do not differ significantly by the test of Tuckey at 5\% of significance. Jaboticabal, SP. 2012.

Table 3: F-values calculated by analysis of variance for corn grain size distribution as affected by different crop systems ${ }^{1}$. Jaboticabal, SP. 2012

\begin{tabular}{lcccccc}
\hline Treatment $^{1}$ & $\begin{array}{c}\text { S18 } \\
\text { (elongated) }\end{array}$ & $\begin{array}{c}\text { S18 } \\
\text { (round) }\end{array}$ & $\begin{array}{c}\text { S20 } \\
\text { (round) }\end{array}$ & $\begin{array}{c}\text { S22 } \\
\text { (round) }\end{array}$ & $\begin{array}{c}\text { S24 } \\
\text { (round) }\end{array}$ & $\begin{array}{c}\text { Bottom } \\
\text { Crop system (S) }\end{array}$ \\
\hline CV $(\%)$ & $1.80^{\mathrm{ns}}$ & $0.34^{\mathrm{ns}}$ & $1.40^{\mathrm{ns}}$ & $1.10^{\mathrm{ns}}$ & $0.88^{\mathrm{ns}}$ & $0.96^{\mathrm{ns}}$ \\
\hline
\end{tabular}

1 ns not significant by the $\mathrm{F}$ test at $5 \%$ of error probability.

Rev. Ceres, Viçosa, v. 63, n.4, p. 576-583, jul/ago, 2016 
even in Cerrado region, where the predominant environmental conditions favor the decomposition rate of organic residues. According to Correia et al. (2013), for the prevailing weather conditions in the north of São Paulo State, it is recommended that the sowing of at least 200 points of cultural value of Urochloa seeds in row is sufficient to maintain adequate amount of straw on the soil for the viability and success of the no-tillage system. The rusticity of the Urochloa species, associated with the characteristic of moderately tolerant to water stress, favors the dry matter accumulation during the off-season period, enabling the planting of succeeding crops in no- tillage system, with satisfactory presence of straw on the soil surface (Pacheco et al. 2011).

Interaction among the factors in the study for the percentage of soil cover was found (Table 4). In the unfolding of the interaction of cropping systems in $\mathrm{N}$ rates applied to the preceding crop, no effect of residual $\mathrm{N}$ was found in the percentage of soil cover for intercropped crop (Figure 3). However, when compared to the sole corn, effect of the cropping cultivation system was found for $\mathrm{N}$ fertilization, in which the increment in the rate in the preceding crop provided higher covering of the soil surface. These results demonstrate that corn grown in

Table 4: F-values calculated by analysis of variance for amount of straw, soil cover, and nitrogen accumulation in straw under influence of residual nitrogen fertilization of common bean on subsequent corn sole or intercropped with Congo grass (Urochloa ruziziensis) in no-tillage system ${ }^{1}$. Jaboticabal, SP. 2012

\begin{tabular}{lccc}
\hline Treatments $^{1}$ & $\begin{array}{c}\text { Amount of } \\
\text { straw }\left(\mathbf{t ~ h a}^{-\mathbf{1}}\right)\end{array}$ & $\begin{array}{c}\text { Soil } \\
\text { cover }(\%)\end{array}$ & $\begin{array}{c}\text { N accumulation } \\
\text { in straw }\left(\mathbf{k g ~ h a}^{-1}\right)\end{array}$ \\
\hline Crop system (S) & $38.63^{*}$ & $1205.55^{* * *}$ & $100.90^{* * *}$ \\
CV $(\%)$ & 7.67 & 3.68 & 13.71 \\
N amount (D) & $1.93^{\text {ns }}$ & $8.26^{* *}$ & $6.86^{* *}$ \\
CV $(\%)$ & 11.55 & 1.97 & 20.24 \\
S x D & $1.15^{\mathrm{ns}}$ & $8.26^{* *}$ & $1.83^{\text {ns }}$ \\
\hline
\end{tabular}

1 ns not significant by the $\mathrm{F}$ test at $5 \%$ of error probability. * Significant by the $\mathrm{F}$ test at $5 \%$ of error probability. ** Significant by the $\mathrm{F}$ test at $1 \%$

Table 5: Amount of straw, soil cover and $\mathrm{N}$ accumulation $(\mathrm{N})$ in straw as affected by different crop system ${ }^{1}$. Jaboticabal, SP. 2012

\begin{tabular}{lccc}
\hline Treatments & $\begin{array}{c}\text { Amount of } \\
\text { straw }\left(\text { ton } \mathbf{h a}^{-1}\right)\end{array}$ & $\begin{array}{c}\text { Soil } \\
\text { cover }(\%)\end{array}$ & $\begin{array}{c}\text { N accumulation } \\
\text { in the straw }(\mathbf{k g} \text { ha-1) }\end{array}$ \\
\hline Crop system & $7.2 \mathrm{~b}^{1}$ & $62.5 \mathrm{~b}$ & $57.3 \mathrm{~b}$ \\
Corn & $8.6 \mathrm{a}$ & $100.0 \mathrm{a}$ & $93.0 \mathrm{a}$ \\
Corn + U. ruziziensis &
\end{tabular}

${ }^{1}$ Means followed by the same letter do not differ significantly by the test of Tukey at $5 \%$ of significance.

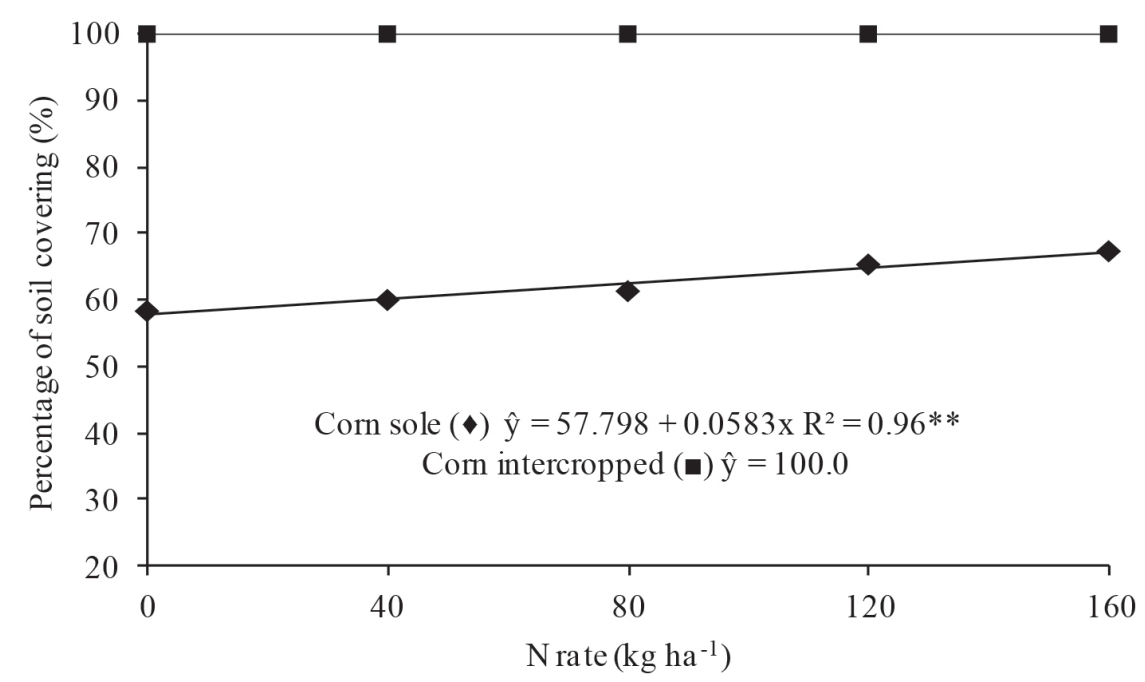

Figure 3: Percentage of soil covering under influence of residual nitrogen fertilization of common bean on subsequent corn sole or intercropped with Congo grass (Urochloa ruziziensis) in no-tillage system. Jaboticabal, SP. 2012. 
sole crop utilized residual fertilization, which favored plant growth and dry matter production.

The intercropping system with Congo grass achieved the highest $\mathrm{N}$ accumulation in the straw, approximately $93 \mathrm{~kg} \mathrm{ha}^{-1}$ (Table 5). According to Souza et al. (2011), $\mathrm{N}$ accumulation in biomass of corn and $U$. ruziziensis, in the second harvest period can reach levels above $140 \mathrm{~kg} \mathrm{~N} \mathrm{ha}^{-1}$. However, these results may vary according to the area, soil and climate conditions during cultivation. In addition to providing improvements in soil chemical properties, positive effects of Urochloa species on soil physical properties have also been reported, due to the high amount of roots of the forage (Silveira et al., 2011).

The application of increasing $\mathrm{N}$ rates in topdressing on the previous crop also favored the $\mathrm{N}$ accumulation in the straw from sole and intercropped system, confirming the recovery of nitrogen fertilizer (Figure 4). Based in regression analysis, the application of $\mathrm{N}$ rates in the previous crop increased linearly $\mathrm{N}$ accumulation in the straw. According to Silva et al. (2006), the knowledge of the residual effect of nitrogen fertilizer on the crop following its application is essential in order to optimize its use and minimize environmental damage.

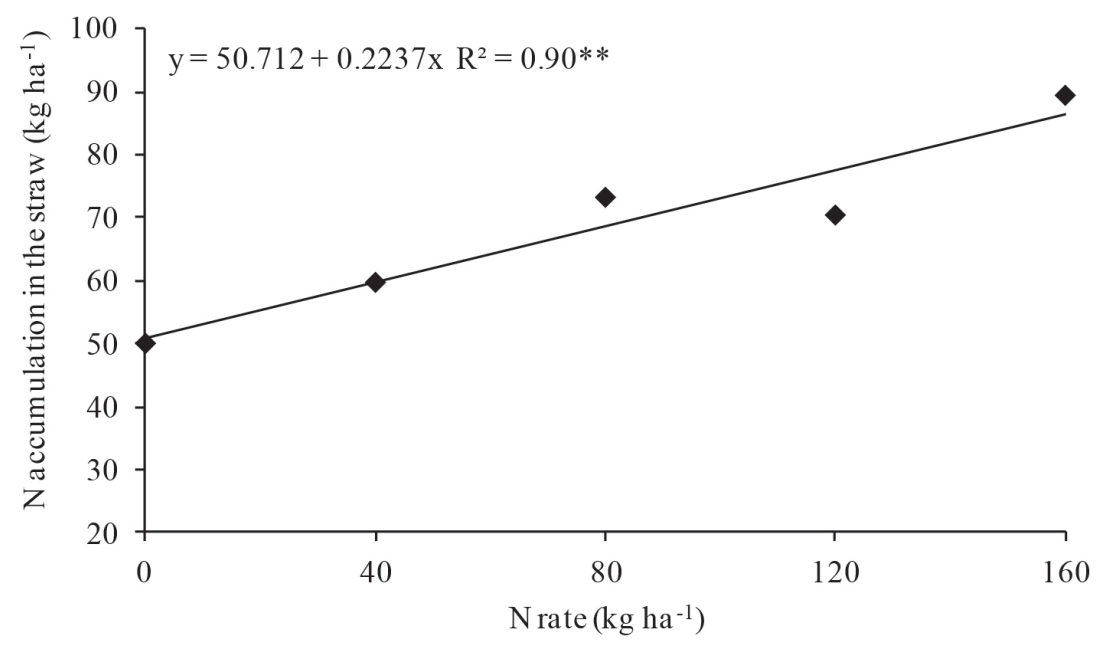

Figure 4: Nitrogen accumulation in the straw of corn sole or intercropped with Congo grass (Urochloa ruziziensis) under influence of residual nitrogen fertilization of commo bean. Jaboticabal, SP. 2012.

\section{CONCLUSION}

Corn intercropped with $U$. ruziziensis leaded adequate formation of straw and full coverage of the soil surface, improving the quality and sustainability of no-tillage system. The intercropping system did not reduce growth and corn grain yield, suggesting that $U$. ruziziensis can be recommended to integrate corn production areas, especially in Cerrado region. Nitrogen fertilization on common bean had no effect in corn cropped in sucession.

\section{REFERENCES}

Amado TJC, Mielniczuk J \& Aita C (2002) Recomendação de adubação nitrogenada para o milho no RS e SC adaptada ao uso de culturas de cobertura do solo, sob sistema plantio direto. Revista Brasileira de Ciência do Solo, 26:241-248.

Andrade RV, Auzza SAZ, Andreoli C, Netto DAM \& Oliveira AC (2001) Qualidade fisiológica das sementes do milho híbrido simples HS 200 em relação ao tamanho. Ciência e Agrotecnologia, 25:576-582.

Batista K, Duarte AP, Ceccon G, Maria IC \& Cantarella H (2011) Acúmulo de matéria seca e de nutrientes em forrageiras consorciadas com milho safrinha em função da adubação nitrogenada. Pesquisa Agropecuária Brasileira, 46:1154-1160.
Baudet L \& Misra M (1991) Atributos de qualidade de sementes de milho beneficiadas em mesa de gravidade. Revista Brasileira de Sementes, 13:91-97.

Chioderoli CA, Mello LMM, Holanda HV, Furlani CEA, Grigolli PJ, Silva JOR \& Cesarin AL (2012) Consórcio de Urochloas com milho em sistema plantio direto. Ciência Rural, 42:18041810 .

CONAB - Companhia Nacional de Abastecimento (2013) Acompanhamento de safra brasileira: grãos. Décimo levantamento julho de 2013. Brasília, Companhia Nacional de Abastecimento. 29 p.

CONAB - Companhia Nacional de Abastecimento (2016) Acompanhamento de safra brasileira de grãos. Nono levantamento maio de 2016. Brasília, Companhia Nacional de Abastecimento. $174 \mathrm{p}$.

Correia NM, Leite MB \& Fuzita WE (2013) Consórcio de milho com Urochloa ruziziensis e os efeitos na cultura da soja em rotação. Bioscience Journal, 29:65-76.

Cunha TPL, Mingotte FLC, Carmeis Filho ACA, Chiamolera FM, Lemos LB \& Fornasieri Filho D (2015) Agronomic performance of common bean in straw mulch systems and topdressing nitrogen rates in no-tillage. Revista Ceres, 62:489-495.

D’Andréa AF, Silva MLN, Curi N \& Guilherme LRG (2004) Estoque de carbono e nitrogênio e formas de nitrogênio mineral em um solo submetido a diferentes sistemas de manejo. Pesquisa Agropecuária Brasileira, 39:179-186. 
Fernandes FCS, Libardi PL \& Trivelin PCO (2008) Parcelamento da adubação nitrogenada na cultura do milho e utilização do $\mathrm{N}$ residual pela sucessão aveia preta-milho. Ciência Rural, 38:11381141 .

Ferreira ACB, Araújo GAA, Pereira PRG \& Cardoso AA (2001) Características agronômicas e nutricionais do milho adubado com nitrogênio, molibdênio e zinco. Scientia Agrícola, 58:131138 .

Fornasieri Filho D (2007) Manual da cultura do milho. Jaboticabal, Funep. 576p

Freitas RJ, Nascente AS \& Santos FLS (2013) População de plantas de milho consorciado com Urochloa ruziziensis. Pesquisa Agropecuária Tropical, 43:79-87.

Kappes C, Carvalho MAC, Yamashita OM \& Silva JAN (2009) Influência do nitrogênio no desempenho produtivo do milho cultivado na segunda safra em sucessão à soja. Pesquisa Agropecuária Tropical, 39:251-259.

Lovato T, Mielniczuk J, Bayer C \& Vezzani F (2004) Adição de carbono e nitrogênio e sua relação com os estoques no solo e com o rendimento do milho em sistemas de manejo. Revista Brasileira de Ciência do Solo, 28:175-187.

Malavolta E, Vitti GC \& Oliveira SA (1997) Avaliação do estado nutricional das plantas: princípios e aplicações. $2^{\mathrm{a}}$ ed. Piracicaba, Potafos. 319p.

Pacheco LP, Leandro WM, Machado PLOA, Assis RL, Cobucci T, Madari BE \& Petter FA (2011) Produção de fitomassa e acúmulo e liberação de nutrientes por plantas de cobertura na safrinha. Pesquisa Agropecuária Brasileira, 46:17-25.

Pariz CM, Andreotti M, Tarsitano MAA, Bergamaschine AF, Buzetti S \& Chioderoli CA (2009) Desempenhos técnicos e econômicos da consorciação de milho com forrageiras dos gêneros Panicum e Brachiaria em sistema de integração lavourapecuária. Pesquisa Agropecuária Tropical, 39:360-370.
Raij B van, Andrade JC, Cantarella H \& Quaggio JA (2001) Análise química para avaliação da fertilidade do solo. Campinas, IAC. 285 p.

Richart A, Paslauski T, Nozaki MH, Rodrigues CM \& Fey R (2010) Desempenho de milho safrinha e da Brachiaria ruziziensis cv. Comum em consórcio. Revista Brasileira de Ciências Agrárias, $5: 497-502$.

Silva EC, Muraoka T, Buzetti S, Guimarães GL, Trivelin PCO \& Veloso MEC (2006) Utilização do nitrogênio $\left({ }^{15} \mathrm{~N}\right)$ residual de coberturas de solo e da ureia pela cultura do milho. Revista Brasileira de Ciência do Solo, 30:965-974

Silveira PM, Silva JH, Lobo Júnior M \& Cunha PCR (2011) Atributos do solo e produtividade do milho e do feijoeiro irrigado sob sistema integração lavoura-pecuária. Pesquisa Agropecuária Brasileira, 46:1170-1175.

Souza ED, Costa SEVGA, Anghinoni I, Carvalho PCF, Andrigueti M \& Cao E (2009) Estoques de carbono orgânico e de nitrogênio no solo em sistema de integração lavoura-pecuária em plantio direto, submetido a intensidade de pastejo. Revista Brasileira de Ciência do Solo, 33:1829-1836.

Souza EFC, Soratto RP \& Pagani FA (2011) Aplicação de nitrogênio e inoculação com rizóbio em feijoeiro cultivado após milho consorciado com braquiária. Pesquisa Agropecuária Brasileira, 46:370-377.

Stone LF, Silveira PM, Moreira JAA \& Braz AJBP (2006) Evapotranspiração do feijoeiro irrigado em plantio direto sobre diferentes palhadas de culturas de cobertura. Pesquisa Agropecuária Brasileira, 41:577-582. 